\title{
The Alien invasive land snail Theba pisana in the West Coast NATiOnal PARK: Is There CaUSE FOR CONCERn?
}

\author{
LIZELLE J. ODENDAAL \\ TANYA M. HAUPT \\ CHARLES L. GRIFFITHS \\ Zoology Department and Centre for Invasion Biology \\ University of Cape Town \\ South Africa
}

Correspondence to: Lizelle J. Odendaal

e-mail: lizelle.odendaal@uct.ac.za

Postal Address: Zoology Department and Centre for Invasion Biology, University of Cape Town, Rondebosch 7700

\begin{abstract}
The distribution, abundance, size distribution and diurnal activity patterns of invasive land snails, Theba pisana, in the West Coast National Park (WCNP), South Africa, were investigated. The park was divided into $1 \mathrm{~km}^{2}$ grids, within each of which five $1 \mathrm{~m}^{2}$ quadrat counts of live snails were recorded. Of 106 grids sampled, 19\% contained live snails. The average density of snails was 4.04 $\mathrm{m}^{-2} \pm 24.9$, significantly lower than in disturbed habitats adjacent to the park $\left(57 \mathrm{~m}^{-2} \pm 96.25\right)$, but very high densities were recorded at two sites. Snails were most abundant along roadsides and densities decreased dramatically with distance from roads. T. pisana in the WCNP appear to have an annual lifecycle, breeding in autumn to winter and growing to adult size of about $14 \mathrm{~mm}$ diameter by the end of the following summer. Snails were observed on a wide variety of endemic and introduced plant species and appeared to have a catholic diet. They are active mostly at night and especially during periods of high humidity, irrespective of temperature. Given the very high densities that T. pisana can attain at some sites, plus their apparently catholic feeding habits, their potential impact on the vegetation of the park is cause for concern and should be further investigated. Control of the main colonies should also be considered.
\end{abstract}

Keywords: Theba pisana, land snail, invasive species, West Coast National Park, impact of alien species invasion

\begin{abstract}
Many human activities, including agriculture, recreation, trade and transport, facilitate the movement of species across natural biogeographic barriers; allowing species that have been separated for millions of years over evolutionary time to interact with one another over ecological time. Only a small fraction of such non-indigenous species introduced to an area becomes established and only some of these become invasive. Nonetheless, they often have far-reaching impacts, many of which are poorly understood (Mooney \& Cleland 2001) and irreversible (Herbert \& Sirgel 2001). Invasive species can also drive local native species to extinction via competitive exclusion (e.g. Lach et al. 2002), niche displacement, or hybridisation with related native species (Mooney \& Cleland 2001). Therefore, besides their economic ramifications, alien invasions may result in extensive changes in the structure, composition and global distribution of the biota of sites of introduction, leading ultimately to the homogenisation of the world's fauna and flora (Olden et al. 2004) and the loss of biodiversity.
\end{abstract}

The Cape Floristic Region (CFR), the smallest of the six recognised floral kingdoms of the world, is an area of extraordinarily high diversity and endemism (Cowling et al. 1996), and is home to more than 9000 vascular plant species, of which $69 \%$ are endemic (Goldblatt \& Manning 2002). Much of this diversity is associated with the fynbos biome (Turpie et al. 2003), a Mediterranean-type, fire-prone shrubland (Turpie et al. 2003; Van Wilgen et al. 2001). The economic worth of fynbos biodiversity, based on harvests of fynbos products (e.g. wildflowers) and eco-tourism, is estimated to be in the region of R77 million a year (Turpie et al. 2003). Thus, it is clear that the CFR has both economic and intrinsic biological value as a biodiversity hot-spot.

While the impacts of alien plants (e.g. alien pines from Australia) (Richardson 1999) and insects (e.g. the Argentine ant, Linepithema humile, and spotted stem borer, Chilo partellus partellus) (Lach et al. 2002) on the fynbos biome are well known, the potential impacts of alien terrestrial snails are poorly understood. Theba pisana (Müller, 1774), a land snail native to the Mediterranean region (Baker 1986), was introduced into South Africa prior to 1881 (Durr 1946), yet has received little attention from researchers, despite the fact that the extent of its invasion in the fynbos biome has been known for some time (MacDonald \& Jarman 1984). T. pisana is a well-known agricultural pest in many parts of the world. In Australia, it feeds on a range of agricultural plants (Baker 1986, 1989) and uses the stalks of cereals as aestivating sites, in turn clogging machinery and fouling produce during harvests (Baker \& Vogelzang 1988). T. pisana is also a significant pest of citrus, vines, legume crops and cereals in South Africa (Durr 1946, Joubert \& Walters 1951) and according to Quick (1952) has been responsible for the extermination of native snail species as a result of competition for available food. Currently, T. pisana is widely distributed in the semi-arid coastal fynbos region of the South Western Cape (McQuaid et al. 1979), and has been recorded as far east as Port Elizabeth (pers. obs.), although it has not been successful in establishing viable populations in the Eastern Cape beyond East London, as this region experiences a significantly different climatic regime to that of the Western and Southern Cape (Herbert \& Kilburn 2004).

In their report on the status and potential impacts of alien invasive organisms in the fynbos biome, MacDonald and Jarman (1984) predicted that T. pisana would have very little impact on ecosystem processes, such as nutrient cycling, energy flow and sediment dynamics or on the germination and succession processes of the plant community itself. However, the snail could seriously impact directly on fynbos plants, by feeding on them, and also displace native herbivores by competing with them for resources, and these effects have not been studied. Thus, the collection of reliable data on T. pisana is urgently 


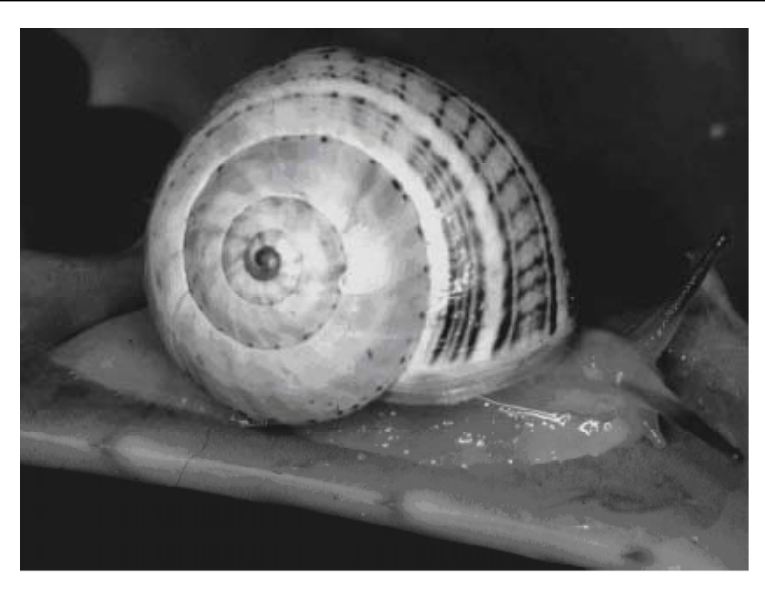

FIGURE 1

Live specimen of Theba pisana in the WCNP

required to assess and mitigate the impacts of the snail, and to better conserve the rich floral diversity of the fynbos.

This study aims to determine the distribution, abundance and size distribution of T. pisana in the West Coast National Park (WCNP), a reserve largely dedicated to the conservation of coastal fynbos. We have also made preliminary observations on the daily activity pattern and feeding ecology of T. pisana within this conservation area. Results of this study can be used to provide a preliminary assessment of the possible impacts of this invasion within the WCNP.

\section{METHODS}

\section{Study area}

Sampling was conducted between March 2006 and January 2007 in the WCNP (35 000 ha) (17o57'E; 33o10'S). The area is characterised by a Mediterranean-type climate with cool, wet winters and hot dry summers (Cowling et al. 1996; Goldblatt \& Manning 2002), has an average rainfall of $265 \mathrm{~mm}$ and is dominated by strandveld vegetation (West Coast National Park 2006).

\section{Data collection}

To establish the density and distribution of T. pisana within the reserve, the entire study area was divided into $1 \mathrm{~km}^{2}$ grids. The mean density of snails in each grid was calculated from five $1 \mathrm{~m}^{2}$ quadrat counts of live snails recorded at $50 \mathrm{~m}$ intervals along a transect line placed within each grid. Since T. pisana have mostly been observed close to roads in the WCNP (C.L. Griffiths pers. obs.), the first quadrat in each line was taken at a random point (determined by vehicle odometer reading) along the roadside, if a road passed through the grid. If no road crossed the grid the transect line was positioned at random. The densities of T. pisana in 11 random areas in and around Langebaan town were also collected in the same manner and compared with the density of snails found within the park. Where snails were observed feeding, or grazing damage was visible around snail colonies, the species of plant consumed was noted. To confirm whether snail densities decreased with distance from the road, at three sites of high snail density five $1 \mathrm{~m}^{2}$ quadrat counts were taken along the road verge and five additional samples at successive $10 \mathrm{~m}$ distances perpendicular

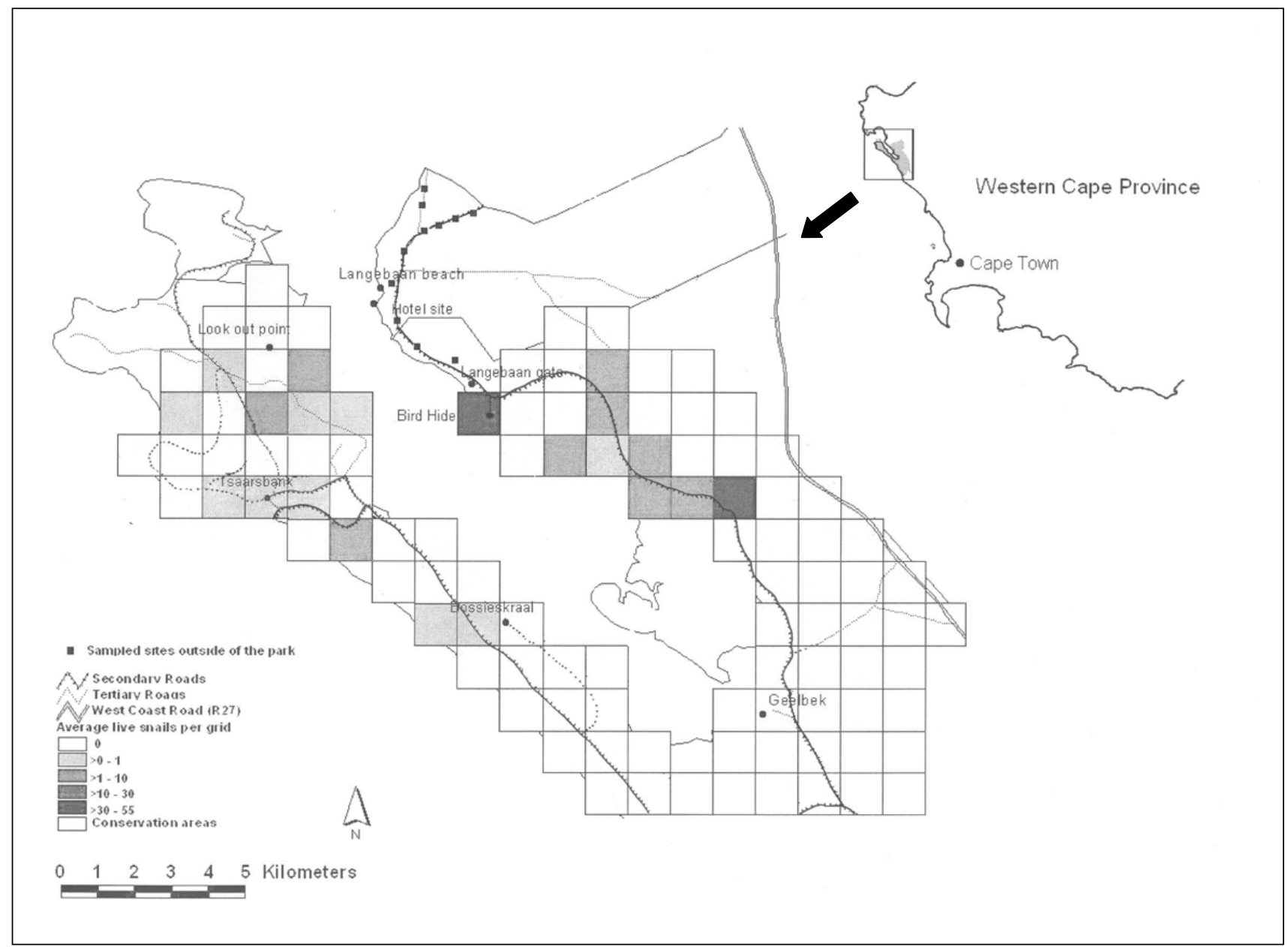

FIGURE 2

Map of the WCNP showing the density $\left(\mathrm{m}^{-2}\right)$ and distribution of Theba pisana in August 2006 as well as the position of sampled sites outside of the Park 


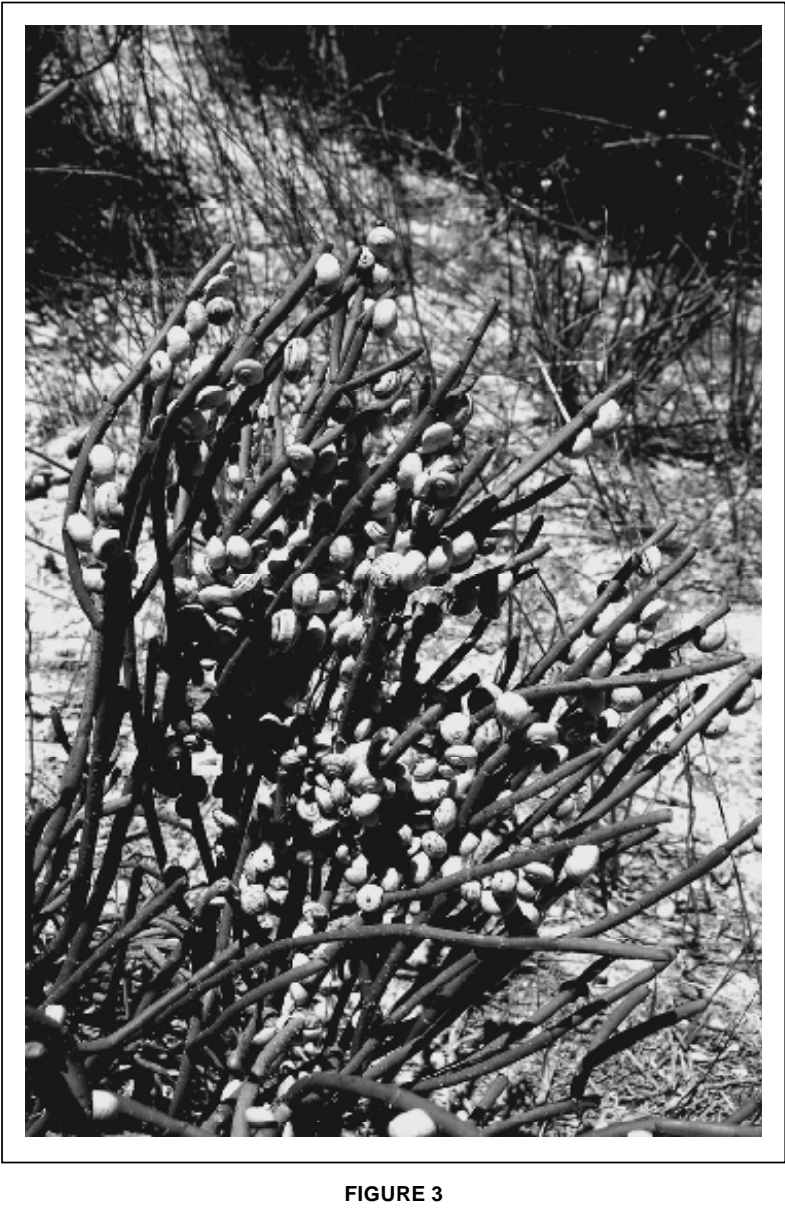

Dense population of Theba pisana at the bird hide in the WCNP

to the road. The average densities of snails, and the position of sampling sites outside the reserve were mapped using Arcview GIS version 3.3 (Esri 2002)

Population structure was determined by measuring the maximum diameter of at least 150 snails (to the nearest $0.1 \mathrm{~mm}$ ) at the same site within the park during March, August and October 2006 and January 2007, using dial callipers.

To determine the diurnal activity rhythm of T. pisana, samples of 70 to 100 snails, together with the vegetation on which they occurred, were collected within the park and placed in open 20L buckets. After 24 hours of acclimatisation, the percentage of snails observed aestivating and active were recorded every two hours over 24 hours. The temperature $(\mathrm{oC})$ and humidity $(\%)$ were also recorded every two hours using a temperaturehygrometer reader. Because the study was done over a short period of time, observations of the feeding duration under various weather conditions were not possible. For example, very humid conditions in which these snails are reported to be highly active were not experienced (Durr 1946). An artificial humid climate was therefore created by placing a plastic bag pierced with holes (to ensure sufficient ventilation) over one of the buckets, after which the contents were moistened with water using an atomiser every four hours. The experiment was repeated under both dry and humid conditions.

\section{Statistical analyses}

Statistical analyses were performed using STATISTICA version 7.0 (StatSoft Inc. 2004). To determine if there were significant differences between the average density of snails within the park and outside the park, nonparametric MannWhitney U-tests were used.

\section{RESULTS}

Theba pisana was the only alien snail species recorded in the surveys. It can be recognised by its shell colour (Figure 1), which ranges from white to yellow-brown with light brown spiral markings (Myburgh \& Rust 1986).

The density and distribution of Theba pisana within the WCNP is illustrated in Figure 2. A total of 106 grids were sampled. Two grids had dense populations of T. pisana averaging between 30 and $55 \mathrm{~m}^{-2}$ (Figure 2). However, one of these contained mostly very young snails $(<5 \mathrm{~mm}$ in diameter), most of which were found in the quadrat closest to the road. The other, at the bird hide, was the most heavily infested area within the park, and quadrat taken along the road contained 300 to 700 snails $\mathrm{m}^{-2}$. The colony extended for approximately $200 \mathrm{~m}$ on either side of an old road, and road-side plants in this area were so coated with snails that they appeared white (Figure 3).

Eighteen per cent of the remaining grids contained live snails, all at densities less than 10 snails $\mathrm{m}^{-2}$ (Figure 2). Interestingly, in many areas where no live T. pisana were found, empty shells were common, attesting to the presence of $T$. pisana in a much larger proportion of the park in the past. The average density (mean \pm SD) of snails outside the park $(57 \pm 96.25)$ (Table 1) was significantly higher than that within the park $(4.04 \pm 24.91)$ (Mann-Whitney; $\mathrm{U}=274, \mathrm{p}<0.05$ ).

The densities of snails decreased rapidly with distance from the road (Figure 4), the most dramatic case being at site two, where the density decreased from 436 snails $\mathrm{m}^{-2}$ to 5.6 snails $\mathrm{m}^{-2}$ within $20 \mathrm{~m}$ and to zero within $50 \mathrm{~m}$ of the road side.

TABLE 1

Mean snail density $\left(\mathrm{m}^{-2} \pm \mathrm{SD}\right)$ at 11 sites adjacent to the WCNP

\begin{tabular}{ll}
\hline SITE NUMBER & AVERAGE SNAIL DENSITY $\left(\mathbf{M}^{-2}\right)$ \\
\hline 1 & $43.8 \pm 53.6$ \\
2 & $3 \pm 6.7$ \\
3 & $54.2 \pm 67.8$ \\
4 & 0 \\
5 & $15.6 \pm 14.5$ \\
6 & $12.8 \pm 6.2$ \\
7 & 0 \\
8 & 0 \\
9 & $2.2 \pm 2.3$ \\
10 & $3.8 \pm 4.1$ \\
11 & 0 \\
Overall mean \pm SD & $57 \pm 96.25$ \\
\hline
\end{tabular}

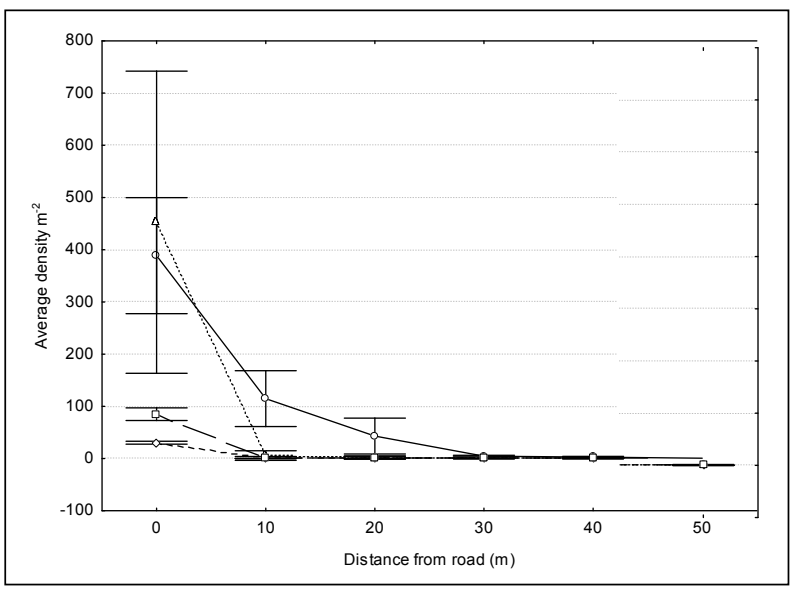

FIGURE 4

Average snail densities $\left(\mathrm{m}^{-2}\right)$ of Theba pisana (mean $\pm \mathrm{SD}$ ) along $50 \mathrm{~m}$ transect extending perpendicular to the road at four sites within the WCNP (Site 1: $\square$, Site 2: $\Delta$, Site 3: $\diamond$, Site $4: \circ$ ) 
TABLE 2

Vegetation species on which Theba pisana was found and possibly predated on, both within and adjacent to the WCNP (all species inside the park are indigenous)

\begin{tabular}{|c|c|c|}
\hline \multicolumn{3}{|l|}{ OUTSIDE } \\
\hline Scientific name & Common name & Family \\
\hline Atriplex sp. & Salt bush & Chenopodiaceae \\
\hline Echium sp. & & Boraginaceae \\
\hline Lactuca sp. & Wild lettuce & Asteraceae \\
\hline Lavatera sp. & Tree mallow & Malvaceae \\
\hline Euphoria helioscopia & Umbrella milkweed & Euphorbiaceae \\
\hline \multicolumn{3}{|l|}{ INSIDE } \\
\hline Euphorbia burmannii & Steenbokbos & Euphorbiaceae \\
\hline Lycium ferocissimum & African boxthorn & Solanaceae \\
\hline Nylandtia spinosa & Tortoiseberry & Polygalaceae \\
\hline Othonna arborescens & Bobbejaankool & Asteraceae \\
\hline Othonna cylindrica & Dikblaar Bobbejaankool & Asteraceae \\
\hline Putterlickia sp. & & Celastraceae \\
\hline Ruschia sp. & & Mesembryanthemaceae \\
\hline Zygophyllum spinosum & Smalblaar Spekbos & Zygophyllaceae \\
\hline
\end{tabular}

TABLE 3

Monthly average temperature $\left({ }^{\circ} \mathrm{C}\right.$ ) and precipitation (mm) during the hottes months of summer at Langebaan over a 30-year period (SA Weather Service, 26 October 2006), compared with that of the previous two summers at the time of the study

\begin{tabular}{|c|c|c|c|c|c|}
\hline & 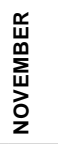 & 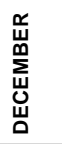 & 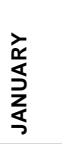 & 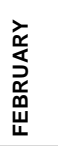 & 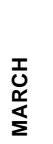 \\
\hline \multicolumn{6}{|l|}{ 1961-1990 } \\
\hline Temperature $\left({ }^{\circ} \mathrm{C}\right)$ & 25 & 26 & 28 & 28 & 27 \\
\hline Precipitation (mm) & 12 & 10 & 8 & 4 & 11 \\
\hline \multicolumn{6}{|l|}{$2004-2005$} \\
\hline Temperature $\left({ }^{\circ} \mathrm{C}\right)$ & 24.7 & 26.6 & 27.9 & 27.2 & 26.5 \\
\hline Precipitation (mm) & 1.6 & 1 & 11.4 & 0.6 & 2.8 \\
\hline \multicolumn{6}{|l|}{$2005-2006$} \\
\hline Temperature $\left({ }^{\circ} \mathrm{C}\right)$ & 23.9 & 25 & 26.8 & 27.4 & 25.6 \\
\hline Precipitation (mm) & 5.2 & 0 & 0.2 & 3.6 & 2.6 \\
\hline
\end{tabular}

Table 2 lists species of plants that T. pisana was found aestivating on. Damage to these plants on which snails occurred abundantly was quite extensive (pers. obs.).

The size distributions of T. pisana during March, August and October 2006 and January 2007 are illustrated in Figure 5. In March, most snails were between 13 to $15 \mathrm{~mm}$ in diameter. In contrast, the majority of snails in August were much smaller ( 2 to $7 \mathrm{~mm}$ ) with very few snails exceeding $10 \mathrm{~mm}$ surviving. Two months later, the juvenile cohort had reached a maximum diameter of $11 \mathrm{~mm}$ (Figure 5) and by January 2007 an average diameter of 14 to $15 \mathrm{~mm}$.

No snails were active during the day and late evening periods during a sunny day (Figure 6a) and only minor activity was noted $<10 \%$ in the early morning $(0: 00-06: 00)$, when the humidity was highest (85 to $96 \%$ ) but the temperature low $\left(4\right.$ to $8^{\circ} \mathrm{C}$ ). On a humid day (Figure $6 \mathrm{~b}$ ) the snails still remained inactive during the day, but showed high rates of activity during the warm night, peaking shortly after nightfall and before dawn, when over $90 \%$ of individuals were active.

\section{DISCUSSION}

The primary objective of this study was to map the distribution and density of the alien invasive land snail, Theba pisana, in the WCNP, with the aim of evaluating its threat to the vegetation of the area.

Currently, T. pisana is restricted to only $19 \%$ of the study area (Figure 2) predominately in areas adjacent to roads and where human activity is highest. However, the presence of large numbers of empty shells in more than $50 \%$ of the grid cells sampled indicates that its distribution has been more extensive in the recent past. While the average temperatures within the Langebaan region rarely exceed $27{ }^{\circ} \mathrm{C}$, the average rainfall in the WCNP during the previous two summers has been considerably less than normal (Table 3). We conclude that the recent low average rainfall of the region has probably resulted in high mortality rates of snails and that the distribution and densities measured here therefore probably represent minimal

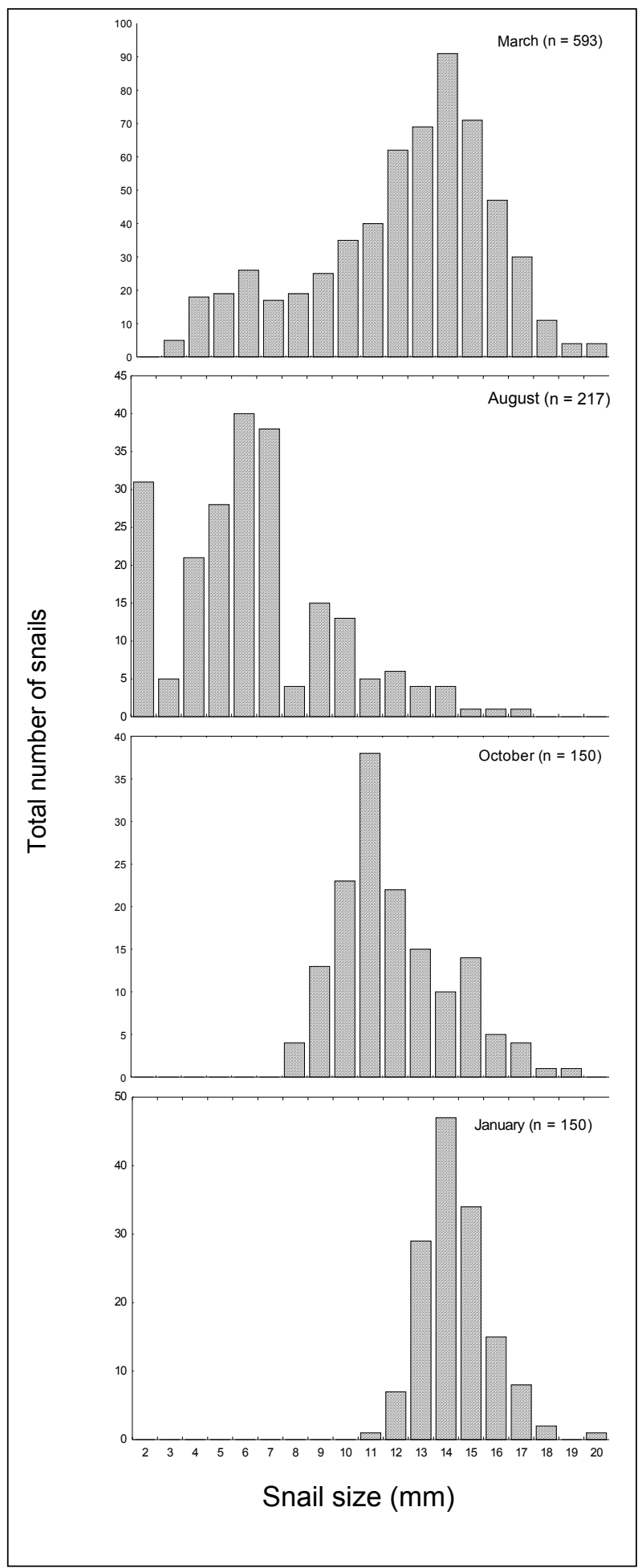

FIGURE 5

Size frequency distributions of Theba pisana in the WCNP in March, August and October 2006 and January 2007 
a)

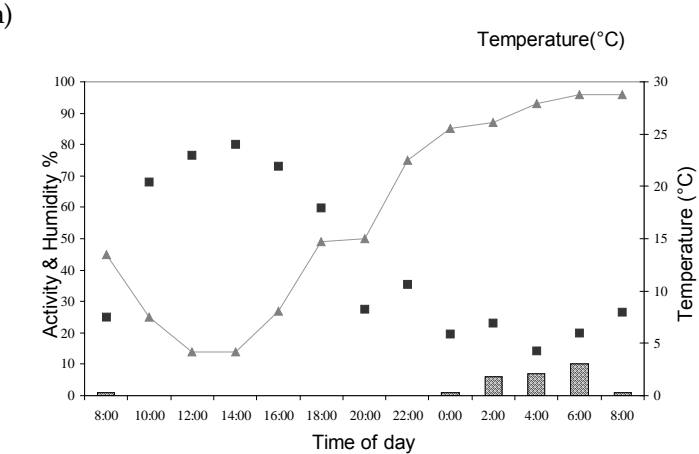

b)

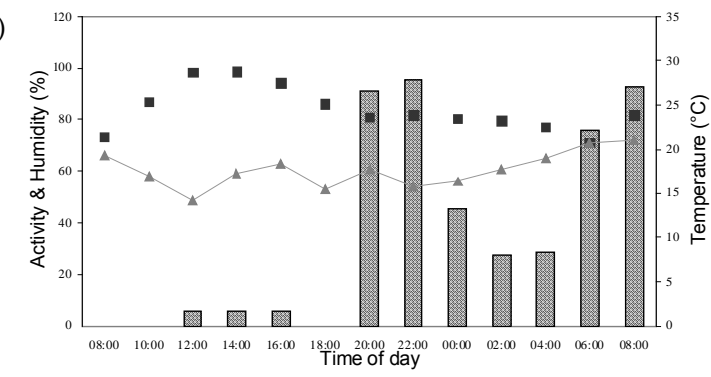

FIGURE 6

Percentage of active individuals in response to temperature $\left({ }^{\circ} \mathrm{C}\right)$ and humidity $(\%)$ during (a) a dry sunny and (b) a humid day

figures, considerably lower than may occur during wetter and more favourable conditions.

Snail populations occur mainly along roads and around existing or abandoned human establishments. At some of these sites densities were extremely high, to the point that snails coated the stems of the vegetation (Figure 3). At such densities it is inevitable that these invasive snails will have significant impacts on the flora, although the nature of such impacts will depend on their feeding rates and dietary selectivity - aspects of their biology that remain unknown at this time. However, several of the plant species on which T. pisana were commonly found is indigenous and showed extensive damage, indicating that $T$. pisana directly impacts the indigenous fynbos flora (Table 3). The presence of such a high biomass of snails is also likely to affect the entire food chain, since they are by far the dominant animal species at these high density sites. More importantly, high density sites did not appear to have a distinct flora, or indeed any other unique characteristics, suggesting that the high snail densities there simply represent a more established population, and that, in time, other areas of the park are likely to become equally seriously infested.

No, or very few, snails were active during the day. At night a few snails became active when the weather was cold (Figure 6a), but on a warm humid night almost all the snails were active, particularly shortly after dusk and in the hours before dawn (Figure 6b). McQuaid et al. (1979) found that T. pisana aroused from aestivation when induced by a combination of low temperature and high humidity. Our preliminary observations agree that activity is promoted by high humidity, but suggest that snails were also active when this was combined with relatively high temperature.

McNeely (2001) argues that many invasive species do well in areas that have been disturbed by human activities. Thus, the low density inside the park could also be due to the relatively undisturbed environment of the WCNP. This is supported by the fact that the average density of $T$. pisana in the severely disturbed areas outside of the park (Langebaan town and adjacent road verges) was more than 14 times higher than that inside the park (Table 1). Furthermore, T. pisana colonies were mainly found in disturbed areas of the park e.g. adjacent to roads and human establishments. Figure 4, showing the decline in snail densities as one moves away from the road at four different sites within the park, further supports this.

In March (the beginning of autumn) the population comprised of mostly adult snails with a mean diameter of $14 \mathrm{~mm}$. By August, most of these adults had disappeared and were replaced by juveniles with the diameter averaging $6 \mathrm{~mm}$. The size of snails increased rapidly during spring and by October, when a unimodal cohort of snails with a diameter of $11 \mathrm{~mm}$ dominated the population (Figure 5), this increasing to $14 \mathrm{~mm}$ by midsummer (January). Durr (1946) stated that oviposition in T. pisana occurs from March to May and that they have an annual life cycle, and our results support these conclusions. Theba pisana in Britain and France have an annual life cycle and breed in summer and autumn, while in the Mediterranean, they have a biennial life cycle with breeding in autumn and winter (Cowie 1985).

In conclusion, it is clear that T. pisana are well adapted to conditions in the Western Cape and can reach very high densities within the WCNP, although our observations of large numbers of dead shells suggest that the population has recently undergone a significant mortality event associated with unusually dry conditions. At peak densities it appears certain that this snail will have profound impacts on the growth and survivorship of favoured food species, although these effects have not yet been quantified. The plant species listed in Table 3 could be used as a starting point for investigating the food preferences of T. pisana.

To date, the mean density within the park is much lower than the density of more disturbed areas outside the park, suggesting that the populations in the park have not yet reached carrying capacity. More research regarding various life history characters of $T$. pisana is required to better understand and identify the impacts of these snails on biotic and abiotic ecosystem processes of the fynbos biome. These include studies that would investigate dispersal rates (using mark-recapture methods), as well as competitive interactions between these snails and other fauna. For example, in their study on the unique use of empty shells of indigenous land snails (several species of Trigonephrus and Tropidophora ligata) as nest sites by several previously undescribed species of silk-spinning wasps belonging to the genus Quartinia, Gess and Gess (2007) found that the relatively small shells of $T$. pisana were unsatisfactory nesting sites for these wasps. Less than $10 \%$ of $T$. pisana shells were used as nests compared to an average use of $53 \%$ of shells from indigenous snails. Also, in areas where T. pisana was present, they were much more abundant than indigenous snails.

Since fynbos is not only globally important as a biodiversity hot-spot biome, but also locally important to the economic wellbeing of the Western Cape, the potential impacts of T. pisana on indigenous flora and fauna is indeed cause for concern.

\section{ACKNOWLEDGEMENTS}

Thank you to Elizabeth Kelly, Melinda Griffiths, Taryn Duthie, Monique Boucher and Bradley Kruger for their assistance in the field, the management of the West Coast National Park for permission to conduct this study and $\mathrm{P}$. Nel for the use of data. Thanks are also extended to D. Herbert and the staff of the GIS lab (University of Cape Town). This study was funded by grants to L.J. Odendaal and T.M. Haupt from the NRF/DST Centre of Excellence for Invasion Biology. 


\section{REFERENCES}

Baker, G.H. 1986. The biology and control of white snails (Mollusca: Helicidae), introduced pests in Australia. CSIRO Australia, Division of Entomology, Technical Paper, 25: 1-31.

Baker, G.H. 1989. Damage, population dynamics, movement and control of pest helicid snails in Southern Australia. In: Hendersen, I. (ed.). Slugs and Snails in World Agriculture, volume 41. Thornton Heath, British Crop Protection Council Monograph, pp. 175-185

Baker, G.H. \& Vogelzang, B.K. 1988. Like-history, population dynamics and polymorphism of Theba pisana (Mollusca: Helicidae) in Australia. Journal of Applied Ecology, 25: 867887.

Cowie, R.H. 1985. Microhabitat choice and high temperature tolerance in the land snail Theba pisana (Mollusca: Gastropoda) Biological Conservation, 78: 207-214

Cowling, R.M., MacDonald, I.A. \& Simmons, M.T. 1996. The Cape Peninsula, South Africa: physiographical, biological and historical background to an extraordinary hot-spot of biodiversity. Biodiversity and Conservation, 5(5): 527-550.

Durr, H.J.R. 1946. A contribution to the morphology and bionomics of Theba pisana (Muller) (Gastropoda: Helicidae). South African Department of Agriculture. Stellenbosch-Elsenburg Science Series, 47: 1-34.

Gess, S. \& Gess, F. 2007. Snail Invasion: The potential impact of the invasive Mediterranean snail, Theba pisana on our coastal dune vegetation. Veld and Flora, 93: 216-218.

Goldblatt, P. \& Manning, J.C. 2002. Plant diversity of the Cape region of South Africa. Annals of the Missouri Botanical Garden, 89: 281-302.

Herbert, D.G. \& Kilburn, D. 2004. Field guide to the land snails and slugs of eastern South Africa. Pietermaritzburg: Natal Museum.

Herbert, D.G. \& Sirgel, W.F. 2001. The recent introduction of two potentially pestiferous alien snails into South Africa and the outcomes of different pest management practices: an eradication and a colonization. South African Journal of Science, 97: 301-304.

Joubert, C.J. \& Walters, S.S. 1951. The control of snails and slugs. Farming South Africa, 26: 379-380.

Lach, L., Picker, M.D., Colville, J.F., Allsopp, M.H. \& Griffiths, C.L. 2002. Alien invertebrate animals in South Africa. In: Pimentel, D. (ed.). Biological Invasions: Economic and Environmental Costs of Alien Plant, Animal and Microbe Species. New York: CRC Press, pp. 267-282.
MacDonald, I.A.W. \& Jarman, M.L. 1984. Invasive alien organisms in the terrestrial ecosystems of the fynbos biome, South Africa. South African National Scientific Programmes Report, No. 85.

McNeely, J. 2001. Invasive species: a costly catastrophe for native biodiversity. Land Use and Water Resources Research, 1(2): 1-10.

McQuaid, C.D., Branch, G.M. \& Frost, P.G. 1979. Aestivation behaviour and thermal relations of the pulmonate Theba pisana in a semi-arid environment. Journal of Thermal Biology, 4: 47-56.

Mooney, H.A. \& Cleland, E.E. 2001. The evolutionary impact of invasive species. Colloquium, 98(10): 5446-5451.

Myburgh, A.C. \& Rust, D.J. 1986. Micellaneous pests. In: Myburgh, A.C. (ed.). Crop Pests in Southern Africa: Deciduous Fruit, Grapes and Berries. Pretoria: Plant Protection Research Institute Bulletin 407, pp. 83-85.

Olden, J.D., Poff, N.L., Douglas, M.R., Douglas, M.E. \& Fausch, K.D. 2004. Ecological and evolutionary consequences of biotic homogenization. Trends in Ecology and Evolution, 19: $18-24$.

Quick, H.E. 1952. Emigrant British snails. Proceeding of the Malacological Society of London, 29: 181-189.

Richardson, D.M. 1999. Commercial forestry and agroforestry as sources of invasive alien trees and shrubs. In: O. T. Sandlund, P. J. Schei \& A. Viken (eds.). Invasive Species and Biodiversity Management. Dordrecht: Kluwer Academic Publishers, pp. 237-258.

South African Weather Service. Climate data for Langebaanweg. Available at: http://www.weathersa.co.za/climat/ climstats/langebaanStats.jsp [Accessed 26 October 2006].

STATISTICA FOR WINDOWS. 2004. Release 7.0. Tulsa, USA: StatSoft Inc.

Turpie, J.K., Heydenrych, B.J. \& Lamberth, S.J. 2003. Economic value of terrestrial and marine biodiversity in the Cape Floristic Region: implications for defining effective and socially optimal conservation strategies. Biological Conservation, 112(1/2): 233-257.

Van Wilgen. B.W., Richardson, D.M., Le Maitre, D.C. Marais, C. \& Magadlela, D. 2001. The economic consequences of alien plant invasions: examples of impacts and approaches to sustainable management in South Africa. Environment, Development and Sustainability, 3(2): 145-168.

West Coast National Park. Park Management Plan October 2006. Available at: http://celtis.sanparks.org/conservation/ park_man/westcoast.pdf [Accessed 20 December 2006]. 